\title{
Shakespeare Remembers! Shakespeare Remembered!
}

David Pearce

\section{(2) OpenEdition}

1 Journals

\section{Electronic version}

URL: http://journals.openedition.org/shakespeare/1963

DOI: 10.4000/shakespeare.1963

ISSN: 2271-6424

Publisher

Société Française Shakespeare

Printed version

Date of publication: 1 April 2013

Number of pages: 225-237

ISBN: 2-9521475-9-0

\section{Electronic reference}

David Pearce, "Shakespeare Remembers! Shakespeare Remembered! », Actes des congrès de la Société française Shakespeare [Online], 30 | 2013, Online since 03 April 2013, connection on 06 May 2019. URL : http://journals.openedition.org/shakespeare/1963 ; DOI : 10.4000/shakespeare.1963 


\section{Shakespeare et la mémoire}

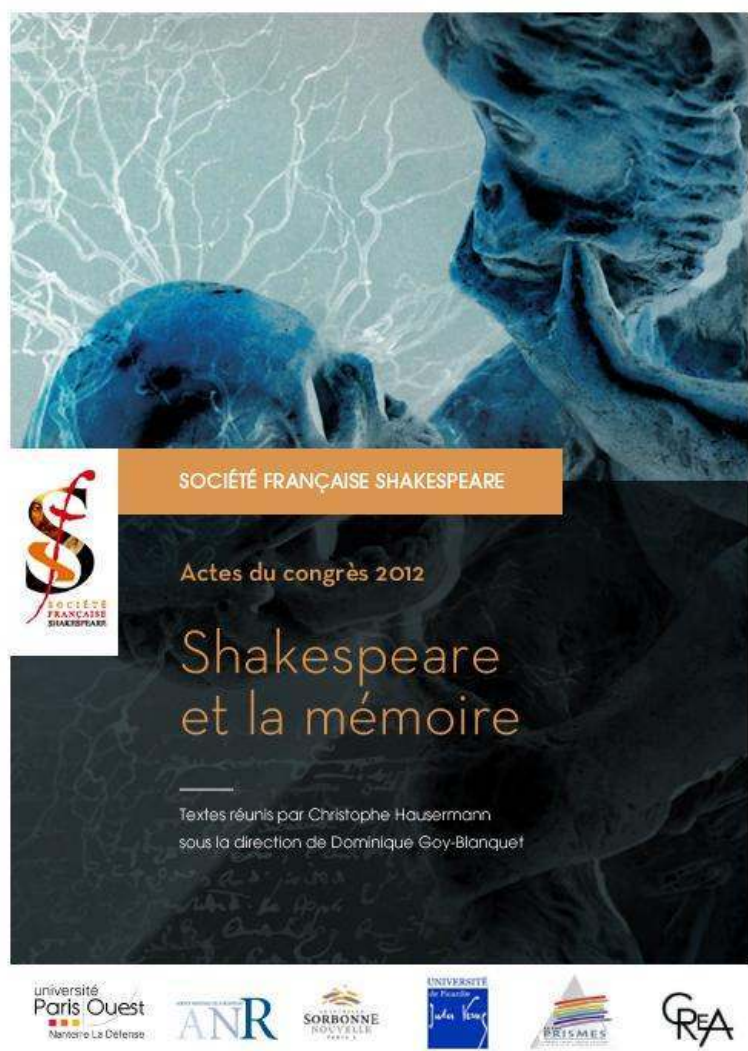

actes du Congrès

organisé par la

SOCIÉTÉ FRANÇAISE SHAKESPEARE

les 22, 23 et 24 mars 2012

textes réunis par

Christophe HAUSERMANN

sous la direction de

Dominique GoY-BLANQUET 


\section{COUVERTURE}

d'après l'affiche de Claire Colombet

conception graphique et logo

Pierre Kapitaniak

mise en page et corrections

Christophe Hausermann

(C) 2012 Société Française Shakespeare

Institut du Monde Anglophone

Université de Paris III - Sorbonne Nouvelle

5 rue de l'École de Médecine 75006 Paris

www.societefrancaiseshakespeare.org

Tous droits de traduction, de reproduction et d'adaptation réservés pour tous les pays 


\title{
SHAKESPEARE REMEMBERS! SHAKESPEARE REMEMBERED!
}

David Pearce

\begin{abstract}
Which plays that Shakespeare himself might have seen would have influenced him to write on the same themes and about the same characters? And which plays of Shakespeare that were viewed by his contemporaries influenced them? And if both of these circumstances occurred, then almost certainly a lot of playwrights observed their contemporaries work at The Rose Theatre, the first playhouse on Bankside.
\end{abstract}

Shakespeare s'est-il inspiré des pièces de ses contemporains et leur a-t-il emprunté leur sujet ou leurs personnages? En retour, lesquelles de ses pièces ont eu le plus d'influence sur ses contemporains ? II est probable que bon nombre de dramaturges élisabéthains ont observé le travail de leurs contemporains au théâtre de La Rose, le premier à s'implanter au sud de la Tamise.

$\mathrm{L}$ ondon.

Today when you say London the image is of Trafalgar Square, Oxford Street, Buckingham Palace and Big Ben. Historically, this is not London. It is the City of Westminster. The Roman City of London that Shakespeare knew was one square mile running from the Tower of London and west into Fleet Street, bordered on the south by the River Thames. That was London, nothing else. In 1596, the City of London government banned play going in The City and the theatres moved outside, four of them directly opposite The City on the south side of the Thames known as Bankside, not in London but in the county of Surrey.

Philip Henslowe was the son of a gamekeeper who became a successful theatre entrepreneur. He owned the Rose Theatre and later the Fortune and Hope Theatres. He also leased or maybe owned for a short time the Newington Butts Theatre, a source of interest we will return to later. After the banning of play going in The City of London in 1596 Bankside became the Theatre Land of Elizabethan London, but Henslowe was already there, entertaining the public when the plague wasn't closing everything down, and he had only recently been joined by the Swan theatre in 1595 .

The great actor Edward Alleyn would become his son-in-law and would crucially preserve his account book, or diary, which now tells us so much about the Rose and what was performed there. 
The first record of the Rose theatre is the lease drawn up in 1586/87 describing the Rose Alleye, the street which still sits beside the Rose today and which the Rose was named after when it was built. It also mentions Maiden Lane, the street name which still survives but which has been reduced in length, so it no longer reaches the site of the Rose as it did in Shakespeare's day. The Rose was a small theatre in terms of what followed. The Swan, Globe and Hope theatres were all approximately double its size, maybe more, but the effect the Rose seemed to have in terms of success almost certainly led to the location of those playhouses.

We will never truly know what Shakespeare's first play really was, but there is an accepted short list of contenders.1 There are many who believe that Shakespeare's first play was either Titus Andronicus or 1 Henry VI. If so then it is possible that the Rose Theatre may have staged Shakespeare's first theatrical work.

Henslowe's Diary furnishes us with accounts relating to the renovation of the Rose from 1592 and describes the purchase of "naylles, rafters, bordes, lyme, ballusters, Itm pd for bryngng of stuff by water and fascinatingly Itm pd for paytinge my stage." These particular details concern the alterations that saw the size of the stage reduced and the playing area therefore become smaller. This has created some debate as a larger stage would surely have been preferable, particularly with the huge amount of characters and spectacle that a play such as 1 Henry VI, to premiere not long after, would demand.

However the renovations also increased the audience capacity and profit margin is thought to have been a motivation. Better facilities, a proper stage roof and better shielding from the sun were also factors. The amount of light that entered the Rose and all the subsequent theatres is a point of interest. It is thought that candlelight was never used in the Bankside playhouses, from what we know performances would start at 2 p.m. and have a duration of two hours, in the winter it does seem therefore that there was enough natural light for a production to reach its conclusion.

1 The Comedy of Errors has been suggested, but I feel it is a bit too polished in terms of its stagecraft, it is definitely early but I seriously doubt the first. More likely, if a comedy was the first subject that Shakespeare turned his hand to, it might be The Two Gentlemen of Verona, since it is stylistically wavering in some points and it provides a slight confusion over geography. However, neither of these plays has been performed at the Rose and this is particularly interesting for us. 
Henslowe informs us that there were many winter productions, the first continuous list of plays the diary presents us with begins on "Satterdaye $19^{\text {th }}$ February 1592" and is the play Fryer Bacon. The Rose was equally acquainted with Christopher Marlowe at this stage and his Jew of Malta was played on $26^{\text {th }}$ February and $10^{\text {th }}$ of March 1592 with Shakespeare's 1 Henry VI between them on the $3^{\text {rd }}$ and $7^{\text {th }}$ of March. On the $23^{\text {rd }}$ of January 1593 Titus Andronicus appears for the first time. In January 1593 there were only 8 days with no performances, so it was almost certainly sometimes cold. But even if candlelight couldn't be discounted on the grounds of expense and impracticality alone then something that Henslowe's Diary doesn't record is also valuable. In the masses of items purchased and recorded there is never once mentioned the purchase of a single candle.

Outdoor theatre in the winter is much more alien to us now but it is of course very difficult to impose many of our modern psychologies into analysing the past, for every similarity we find in one aspect of life in Shakespeare's time, we can find an opposite from our present day. Even if we focus solely on the arts this is very apparent. Plays were not regarded then as the high literature that they are today, a play such as Hamlet, which now seems to intimidate many people into avoidance such is its reputation and sheer length, in Shakespeare's day sat alongside everything else highly admired but not necessarily towering over everything around it.

Modern comparisons of Shakespeare's artistic achievements are difficult but they perhaps exist in a way in which we can compare more contemporary artists' work to each other. For instance, we can compare Akira Kurosawa's Throne of Blood (Macbeth) to his own Ran (King Lear). Another director who perhaps did more than any other to implant Shakespeare on the screen is Orson Welles, whose Chimes at Midnight can also be compared to his own Macbeth or Othello. Similarly, we can compare Ingmar Bergman's Smiles of A Summer Night (based on A Midsummer Night's Dream) to Franco Zeffirelli's Romeo and Juliet. These artists are to cinema what Shakespeare was to literature.

It is more difficult for art to disappear today thanks to our modern media outlets, as so many of Shakespeare's contemporaries' works have disappeared, so there is less to compare Shakespeare to in his own era. It is assumed by many that Shakespeare's plays were 
artistically elevated above that of the vast majority of his fellow writers as soon as just seven years after his death.

John Heminges and Henry Condell, with Ben Jonson's patronage, preserved all of his work in the original folio, without which we would only have access to half of all Shakespeare's plays that would remain in the surviving quartos. Some, like Romeo and Juliet, would be inferior texts to what the first folio later provided.

The point behind my comparing our modern masters of the cinematic art to Shakespeare's contemporaries is to highlight the fact that today art has a better chance of surviving, technology has gifted us the ability to revisit. How many people have in the last five or six years logged on to YouTube in the hope of finding something from their vague memory to discover that there it is again in front of them, available once more because someone else preserved it in a thirty-yearold recording.

Time has been less kind in preserving many of the same parallel examples of Shakespeare's fellow writers. But within this comparison of now and then there is an important point, both psychologically and artistically (and in terms of today's continuing royalties financially). Today we do not have to remember! We do not have to remember on the same level when it comes to a piece of writing or performance infecting our conscience, there is perhaps less mental absorbing of the art in the moment, and the principal cause is that it is easier to see again a piece of art today than it was 400 years ago.

A piece of music, a film, a television programme, even books and painted art are more accessible through different media. We do not have to remember so much because today we have the ability to see a piece of work once more very easily. It allowed our memory / concentration to relax focus and the ability to view again has in many cases diluted the initial impact through the ease of overfamiliarity.

This is not to suggest that the Elizabethan audience sat, or stood with opened-mouth wonder in complete silence for two hours at every performance. This suggestion would be as ridiculous as the complete opposing cliché, often promoted to children by teachers, that the audience would have shown their disappointment or disapproval with aspects of the productions by throwing tomatoes or some other type of fruit. Analysing the wildlife and fruit and flowers that Shakespeare so lyrically describes is a worthwhile cause. In the case of tomatoes, they 
were not recorded in England until 1597, 10 years after the construction of the Rose Theatre, and at that point were regarded as poisonous, not suitable for eating. Perhaps this is why, even if Shakespeare had been aware of tomatoes he did not refer to them in his plays, in stark contrast to the amount of the other fruit, herbs, trees and flowers he mentions. The obvious country of thought when thinking about tomatoes today is Italy, but if people took time to research they would discover that even there until the late 1600's (certainly at least 50 years after Shakespeare died) tomatoes were only used as table decorations.

This may sound like digressing, but it also means that Shakespeare would not have picked up on the existence of tomatoes from any of his Italian sources. Where we know the documented historical fact of the Roman tragedies were sources of great interest, so too was more recent Italian literature such as Giovanni Boccaccio's The Decameron. The Decameron is the source and basis of elements of The Merchant of Venice, Othello, and especially All's Well That Ends Well.2 In Boccaccio we do find, in the "Introduction to the Third Day", vivid descriptions of a beautiful walled garden containing both orange and lemon trees. 3

Oranges were known in the Mediterranean at this time, and lemons were cultivated in Europe for the first time in Genoa in the mid 1400's. Therefore, oranges and lemons are referred to in Italian literature, which Shakespeare would have known of, even if through translation, and he uses them in his texts, even to the degree that by mentioning a lemon only once and orange twice this suggests the fact that such fruits were cultivated in England only by the very wealthy who could afford private conservatories, any other access to such fruits would have been importation, therefore expensive. The quintessentially English and much more available apple by contrast, is mentioned around 30 times in Shakespeare's works, implying a greater familiarity.

From this we therefore move to the realisation that Shakespeare had the memory of not just local London people or the English to rely on, but a multitude of foreign visitors as well. Shakespeare would most probably have had the knowledge of other plays contemporary to his

2 Set in Florence as the source story.

3 The Decameron, ed. G. H. McWilliam, London, Penguin Classics, 1995. 
works, and key to some opinions, is the fact he almost certainly witnessed himself some plays which are lost to us. Some of these were performed at the Rose Theatre, in fact three plays that must have had strong Italian themes: The Italian Tragedy (1602) by Wentworth Smith, The Venetian Comedy (1595) Anon., and The Fair Maid of Italy (1593/94) Anon. Unfortunately, these three plays have been lost.4

On 10th January 1599, Henslowe entered in his diary a £2 payment to playwright John Day for a piece of work which the recorded diary entry highlights as having an unfinished title, The Italian Tragedy of...5 It seems that this play, which was unfinished, had never been performed. But in March 1602, three years later, Henslowe paid the playwright Wentworth Smith for his very similarly titled The Italian Tragedy. It seems very unlikely that these were the same plays as they were written by different men for different acting companies. At the time the unperformed play by John Day was listed while the acting company of Nottingham's men were in residence at the Rose. By the time of Wentworth Smith's production, Worcester's men had moved in.

The point to highlight is that this illustrates the depth of influence that Italy was having, both culturally and literally. We do not know what these plays contained and therefore what Shakespeare himself may have seen at the Rose, in these plays, that could have given him ideas for characters and story, or historical and geographical facts.

How many other things did Shakespeare remember and take from other works that no longer exist for us to analyse? In terms of financial ambitions, it seems a fairly accepted logic can be applied. If a particular subject matter or characters appealed to an audience as told by one playwright, then surely the same audience would return for a different interpretation on the same or slightly different theme, with the same or only slightly different characters.

Henslowe's diary furnishes us with a list of plays, mostly lost, that both pre- and postdate plays that Shakespeare himself wrote. Henslowe also kept records for some of Nottingham's Men's performances performed in other places than the Rose:

4 See The Lost Plays Database (www.lostplays.org).

5 Documents of the Rose Playhouse, ed. Carol Chillington Rutter, Manchester Press, revised edition, 1999. 
Cardinal Wolsey, Parts 1 and 2, performed 1601 - LOST. Predating Shakespeare's characterization in Henry VIII (All Is True) by over a decade.

Malcolm King of Scots - (predating Shakespeare's Macbeth) performed 1602 - LOST.

Among plays with similar themes performed at the Rose were:

Buckingham (1590) - LOST. Predating Shakespeare's Richard III.

Caesar and Pompey (1594) - LOST. Predating Shakespeare's Julius Caesar and Antony and Cleopatra.

The Famous Victories of Henry V (1598) - Survives. Predating Shakespeare's Henry $V$.

Troy and Troys Revenge (1592 and 1599 respectively) - LOST. Both predating Shakespeare's Troilus and Cressida.

King Leir (1588) - performed $6^{\text {th }}$ and $8^{\text {th }}$ April 1593 predating Shakespeare's King Lear.

Philip Henslowe also paid Henry Chettle and Thomas Dekker for a play of Troilus and Cressida before Shakespeare's version of that story, but it's not recorded as being performed.

Although Shakespeare clearly worked from other sources as well, we cannot know if he saw these plays at the Rose, the only theatre on Bankside at the time of most of these performances. He surely saw some if not all of them, and took details, dialogue, characters and theatrical ideas from them. At this moment in his career, he was still learning, although very quickly.

There are other examples of plays that might have inspired him. Titus and Vespasian is a 1591 lost play. It is difficult to determine whether this was composed before or after Shakespeare's Titus Andronicus but it was performed at the Rose a year or so earlier. If Shakespeare was inspired to write Titus Andronicus following this now anonymous play, then he outperformed it at the box office quite convincingly according to Henslowe's accounts.

Of course there were other plays on similar themes at the Rose that definitely came after Shakespeare's interpretations of the same stories and characters:

Richard Crookback by Ben Jonson, Henslowe paid Jonson £10 for this play in 1602 - LOST And it doesn't seem it was ever performed despite payment. This postdates Shakespeare's Richard III.

Sir John Oldcastle (1599) - Survives. Postdates Shakespeare's Henry IV. 
Is it possible these plays were commissioned on the back of the success of Shakespeare's plays? Of course it wasn't just the theatres, their owners and the writers that made everything function. There were a number of different acting companies in this period, some would naturally break away and mould into other groups for reasons of disagreement or death of a patron or even lack of continuing success. Lord Strange's Men became Derby's Men when Ferdinando Stanley inherited the title of Earl of Derby upon his father's death in September 1593. Therefore from September 1593 to 16 April 1594, a period of only eight months, they were Derby's Men. Upon the new Earl of Derby's untimely early death on 16th April 1594, Derby's Men soon after reorganised into the Lord Chamberlain's Men, the company that Shakespeare would very shortly and very famously spend the rest of his career with. They were under the wing of Henry Carey, Baron Hunsdon, Lord Chamberlain to Elizabeth I.

It was in this fledgling company that they performed at Newington Butts in 1594, a theatre that Henslowe had bought or leased in addition to the Rose. The Admiral's Men were already set up when Edward Alleyn joined them in 1585. Thereafter, they became the powerhouse acting company history records them as.

For a brief tenure, the Admiral's Men and Lord Strange's Men occupied the Theatre in Shoreditch together but in May 1591, a disagreement between Edward Alleyn and actor Richard Burbage led to the end of the theatre sharing. They did however reform intermittently during the plague closures of the theatres from 1592 to 1594, and it was under this structure (with Lord Strange's Men, now called Derby's Men and soon to be Lord Chamberlain's Men) that the performances at Newington Butts took place between June $3^{\text {rd }}$ and June $13^{\text {th }}$. Both the Admiral's Men and the future Lord Chamberlain's Men were performing at the same time in the same theatre for this 11-day period. But what of Shakespeare?

The Newington Butts theatre had been in existence since 1580 at least, but being situated near what is the modern day Elephant and Castle, this was not a good location. Nevertheless, Henslowe had two performance spaces to oversee. The performances at Newington Butts are recorded in Henslowe's diaries alongside the Rose Theatre's productions. After the eleven days spent at Newington Butts, the Admiral's Men returned to the Rose, and the Lord Chamberlain's Men 
installed themselves at The Theatre to the east of London until 1598. But what of those performances from 3-13 June 1594?

The earliest document linking Shakespeare with Lord Chamberlain's men is December 1594. We know that plays were virtually always sold in one payment, there were no continuing royalties for every production. Away from directly artistic aspirations Shakespeare's audience, or some of them, had other reasons for remembering or attempting to remember a great play. What many scholars believe one of these examples to be is a play that protrudes directly from Shakespeare's body of work and also involves the Rose Theatre's creator Philip Henslowe.

The Taming of the Shrew, or in its slightly alternate title The Taming of a Shrew, was performed by the Earl of Pembroke's Men. The Taming of a Shrew has been much discussed. But it is generally agreed that this text is a pirate version of Shakespeare's play. The 1594 "bad quarto" represents a poor version of what Shakespeare later produced. Were Pembroke's men attempting the ultimate challenge in terms of memory and the theatre - to remember an entire production, rewrite it and perform it for themselves? The play was performed at Newington Butts on 11th June 1594, and it was the Lord Chamberlain's Men who performed it, but it is never mentioned in Henslowe's diary as being performed at the Rose.

Under this theory does admittedly lie the question that Pembroke's Men would have seen the show somewhere else first. We do know that later they sold their plays (including The Taming of a Shrew) and costumes when they hit hard times. This seems to be just prior to the Newington Butts performance. Was Shakespeare attempting to "reclaim" the play in a revised version of his own at the Newington Butts performance? As The Taming of a Shrew version still exists we can be certain Shakespeare didn't authorise this because it does not bear comparison with the first folio. But the most interesting point is that Pembroke's Men had used their memories for financial reasons rather than artistic reflection.

A production of Hamlet took place on 9th June 1594. It is generally thought that this Hamlet recorded by Henslowe is Thomas Kyd's. But it has been suggested that this performance could have been Shakespeare's. We will never know for sure who wrote the Hamlet staged at Newington Butts on 9th June 1594. There is a greater 
likelihood that The Taming of a Shrew was Shakespeare's, but a more interesting question emerges. It is mostly accepted that by the time of these June 1594 Newington Butts performances, Shakespeare was already with the Lord Chamberlain's Men and not the Admiral's, however the Admiral's Men performed his Titus Andronicus the same week twice, the $5^{\text {th }}$ and 12th of June, between Hamlet and The Taming of a Shrew. So two different companies were performing two (maybe three?) of Shakespeare's plays in the same theatre owned by Henslowe in the space of a week.

The first known involvement of Shakespeare with the Lord Chamberlain's Men as a company member is December 1594 - six months later. So, is it possible that at the time of the June 1594 Newington Butts performances of Titus Andronicus, The Taming of a Shrew, and Hamlet, if we could accept it as Shakespeare's, that he was not affiliated to either company? Was he in fact "freelancing" in this short period, both as actor and playwright? Was he intending to rewrite The Taming of a Shrew or write a superior version of Kyd's play?

It is known from the diaries however that The Taming of a Shrew, Hamlet and Titus Andronicus took less money at the Box Office that week than the Admiral's Men's new play Bellendon, which sold fantastically when it was performed at the Rose on 2nd July. That anonymous Italian-sounding play is now lost. Is it possible that within that June 1594 period the Admiral's Men, the Rose's company, may have been unimpressed with Shakespeare? Did they feel that after the brilliance of 1 Henry VI and Titus Andronicus at the Rose he was fading in terms of his output, and did The Taming of a Shrew and Hamlet prove it? Or did they simply feel they had enough new writing coming in and the repertoire they were already working from was enough? Or was Shakespeare, as is widely believed, already working with the Lord Chamberlain's Men? Or was he in a position to choose which company he joined? Was he courted as a writer and actor by both companies? If he was, then there was an interesting choice to make, as the Lord Chamberlain's Men did not yet have the Theatre in Shoreditch for their own performances. Talks may have been ongoing, but this was still just after two years of near constant plague.

The Admiral's Men had their own theatre. However, the Lord Chamberlain's Men had the Lord Chamberlain, as such they were almost certain to find a home if they weren't lined up for one already. 
Maybe Shakespeare did choose, maybe the Admiral's Men did decline his future services, or perhaps most likely he was already with the Lord Chamberlain's Men at the time that ten-day run of shows had started.

History tells us that, shortly after, Shakespeare was with the Lord Chamberlain's Men at the Theatre in Shoreditch in summer and at the Cross Keys in winter until the banning of theatre in 1596. Five years later, he and the company settled at the Globe.

Regular play entries for performances at the Rose ended in November 1597. There are still quite a lot of recorded performances thereafter but nowhere near as frequent. Six months earlier on $11^{\text {th }}$ of May 1597, Henslowe recorded the performance of a play that when printed two years later was entitled An Humourous Days Mirth by George Chapman. In the diary however he listed it as The Comedy of Humours. This was an accepted term for a particular genre of Elizabethan play, but this seems to be the only time it was used as a title.

The only performance of Shakespeare's Comedy of Errors before this was at Grays Inn on $28^{\text {th }}$ December 1594 but the fact that it was performed again at Christmas 1604 for James I could indicate that it had other undocumented performances and a good word of mouth. Therefore is it conceivable that Henslowe may have advertised $A n$ Humourous Days Mirth under an alternate title to exploit the association of the similarly sounding Shakespeare work?

The first extensive list of performances at the Rose after the opening of the Globe theatre runs from the $6^{\text {th }}$ of October 1599 , just over two weeks after Thomas Platters account of Julius Caesar at the Globe on $21^{\text {st }}$ September, and in this initial period, running through to the following year the Rose seems to be financially healthy.

Shakespeare became a memory for the Rose and the Rose became a memory for Shakespeare, at least it would have done if, between the years 1599 and 1606, it hadn't been sitting fifty metres across the street. Thereafter the Rose had been joined by too much competition, it was too small to compete against the Globe and the Swan, and when the lease ran out Philip Henslowe was already occupied with his new Fortune Theatre. Seven years later he would open the Hope Theatre, where, even though he and Jonson had had disagreements over Richard Crookback years earlier, they were probably forgotten as his Bartholomew Fair played there successfully. 
On the $9^{\text {th }}$ of May 1603, just two months after Elizabeth I's death, Henslowe recorded that he already had a licence from the new King for Worcester's Men to perform at the Rose but the theatre was now approaching its autumn. On $25^{\text {th }}$ June 1603 Henslowe wrote of a conversation which recalled he would be asked for $£ 20$ to renew the lease on the site. This was a substantial increase from $£ 7$ just a few years earlier. He was also being asked for another 100 marks for building. When met with this virtual extortion, he stated categorically that he would rather pull the playhouse down.

When Edward Alleyn retired in 1604 he founded Dulwich college in South East London and took his father-in-law's diary's (account books) and it has remained there ever since. After the last recorded performance at the Rose in 1603, the lease on the site was therefore not renewed, and after the last diary account by the sewer commission in 1606 the Rose was most likely pulled down and its timbers sold on. It returned to being rural land and later tenements.

After the bombings of the Second World War, an office block was built on the site, which in turn was demolished in the late 1980's. It was at this time in 1989 that the archaeologists from the Museum of London moved in and discovered the brick foundations of the two stages and outer and inner walls. Items discovered included jewellery, coins and parts of money boxes used to collect box office takings.

The site was scheduled to be completely covered over shortly after this, but the Rose Theatre Trust and an international media campaign aided by many well known prominent actors helped to prevent this and preserve the site for more future discovery and English Heritage became the Guardians of the site in June 1989.

Approximately two thirds of the site have been uncovered but financial limitations have meant that the digging had to be put on hold. It is in these circumstances that we are able to perform plays on the section of the site that is awaiting excavation, and in regards to the archaeology there is an Indiana Jones's element to the Rose today. We do not know for certain how the audience entered the galleries for example, and it's possible we are currently performing on top of an undiscovered stair turret.

It is our hope that very soon the archaeological excavations can resume. The Rose today is no longer a memory, it is the present. We hope it will be the future too. 


\section{EPILOGUE}

JANUARY 2013 AFTERWORD

On the $15^{\text {th }}$ November 2012 it was announced at a breakfast event held at the British Museum that the Rose revealed project had been awarded a development grant from the Heritage Lottery Fund to work up the plans to preserve the site and to create a visitor and performance centre.

David Pearce

Rose Theatre Bankside 